\title{
Effect of Trace Elements from Consumption of Crops Cultivated on Mine Domes (Spoils): A Case Study of Jos Plateau and Environs, Central Nigeria
}

\author{
Raymond Revelation Dakar ${ }^{1}$, Umaru Umaru Nahabu ${ }^{1}$, Adamu Yunusa Ugya ${ }^{2}$, \\ Tijjani Sabiu Imam², * \\ ${ }^{1}$ Federal College of Animal Health and Production Technology, National Veterinary Research Institute, Vom, Jos, Nigeria \\ ${ }^{2}$ Biological Sciences Department, Bayero University, Kano, Nigeria
}

Email address:

tsimam.bio@buk.edu.ng (T. S. Imam)

${ }^{*}$ Corresponding author

To cite this article:

Raymond Revelation Dakar, Umaru Umaru Nahabu, Adamu Yunusa Ugya, Tijjani Sabiu Imam. Effect of Trace Elements from Consumption of Crops Cultivated on Mine Domes (Spoils): A Case Study of Jos Plateau and Environs, Central Nigeria. International Journal of Pharmacy and Chemistry. Vol. 3, No. 5, 2017, pp. 67-71. doi: 10.11648/j.ijpc.20170305.12

Received: May 30, 2017; Accepted: August 26, 2017; Published: October 26, 2017

\begin{abstract}
The study was conducted on the Jos Plateau metropoly and its environs in Jos North, parts of Jos South and Barkin-Ladi Local Government Areas of Plateau State, Central Nigeria. The studied area covered south eastern part of Naraguta sheet $168 \mathrm{NE}$, extends down North eastern part of Kurra sheet $189 \mathrm{NE}$ bounded by Longitude $8^{\circ} 50^{\prime} \mathrm{E}$ to $9^{\circ} 00^{\prime} \mathrm{E}$ and Latitude $9^{\circ} 26^{\prime} \mathrm{N}$ to $9^{\circ} 43^{\prime} \mathrm{N}$ respectively. This area sampled covers a land mass of about 586.25 square kilometer. This study begins from May, 2009 to March, 2016 at the National Veterinary Research Institute (NVRI), Vom. The aim was to investigate the effect of trace elements from consumption of crops cultivated on mine domes (spoils). The results presented in this paper refer to Tomato and Irish-potato, which are the most popular crops planted in that area in 2009-2016 respectively. Energy Dispersive X-Ray Fluorescence spectrometry(ED-XRFS) method was employed for the analysis of $\mathrm{Cu}, \mathrm{Fe}, \mathrm{Zn}, \mathrm{Ni}, \mathrm{Pb}, \mathrm{Cr}$ and $\mathrm{Mn}$. This study concluded that all those concentrations are well below threshold limit values accepted in Nigeria. No significant differences in $\mathrm{Cu}, \mathrm{Pb}$ and $\mathrm{Cr}$ concentrations between the tested Tomato and Irish-potato were found. Zinc concentration in Potato was significantly lower than in Irish potato. Generally, the study concluded that plant samples were found to have major, minor and mostly trace elements' concentrations below the safe values. However, $\mathrm{Pb}$ that has high concentration above the safe value (threshold limit) in Potato is advised not to be cultivated around mine domes, because of its health adverse effects on the inhabitants.
\end{abstract}

Keywords: Mine, Domes, Concentrates, Trace Elements, Tomatoes, Irish Potatoes

\section{Introduction}

Trace elements play a significant role in many metabolic processes in plant organisms, but at excessive concentrations, particularly in soluble forms and easily available to plants, can cause phytotoxic symptoms. Plant response to high contamination of soil and air with heavy metals is extremely variable and depends on many environmental factors [1] [2]. Soluble and colloidal forms of heavy metals suspended in a soil solution are the most important for plant uptake, and the most important factors influencing their availability and their total concentration and soil reaction [3]. The accumulation of heavy metals and metalloids in agricultural soil is of increasing concern nowadays. Potentially harmful metal in soil may come from the bedrock itself and anthropogenic sources like solid or liquid waste deposits, agricultural inputs and fallout of industrial and urban emissions [4]. Excessive accumulation in agricultural soils results in soil contamination and has consequences for food quality and safety. Food is the major 
intake source of toxic metals by human beings. Among food system, vegetables are the most exposed food to environmental pollution due to aerial burden. Vegetables take up heavy metals and accumulate them in their edible and non-edible parts at quantities high enough to cause clinical problems to both animals and human beings. Excessive content of metals beyond Maximum Permissible level (MPL) leads to number of nervous, cardiovascular, renal, neurological impairment as well as bone diseases and several other health disorders [5] [6] [7]. Vegetables are an essential part of diet and are taken both cooked and in raw forms by human. Vegetables act as buffering agents for acid generation during digestion [8], and some metals present in vegetables are even important biochemically and psychologically from health point of view. Metals like cobalt $(\mathrm{Co})$, chromium (III) $(\mathrm{Cr})$, copper $(\mathrm{Cu})$, iron $(\mathrm{Fe})$, manganese $(\mathrm{Mn})$, molybdenum $(\mathrm{Mo})$, selenium $(\mathrm{Se})$ and zinc (Zn) help in regulating human metabolism [9]. Manganese is an essential elements act as an activator and constituent of many enzymes present in human [10]. But some elements like $\mathrm{Pb}, \mathrm{Cd}$, As are very toxic for human. Lacatusu et al. [11] reported that soil and vegetables contaminated with $\mathrm{Pb}$ and $\mathrm{Cd}$ have potential health implication to the people who consumes those vegetables. The purpose of the present study was to assess the concentrations of some selected heavy metals in tomato fruits and Irish potato tubers cropped in an immediate vicinity of mine domes, of Jos metropoly and its environs.

\section{Materials and Methods}

\subsection{Study Area}

The study was carried out at the Livestock Investigation Division (LID) of National Veterinary Research Institute (NVRI), Vom and partly at the University of Jos. Vom is located in Jos South Local Government Area of Plateau State and at an altitude of about $4200 \mathrm{ft}(1280 \mathrm{~m})$ above sea level. It is $8^{\circ} 45^{\prime}$ East, $9^{\circ} 431$ North of the Equator with an average rainfall $1300 \mathrm{~mm}$ to $1500 \mathrm{~mm}$ and the rainy season extends from late March to early October. The average daily minimum temperature is $17^{\circ} \mathrm{C}$ and the highest mean monthly maximum temperature is $31.1^{\circ} \mathrm{C}$. The lowest mean monthly minimum temperature is $13.9^{\circ} \mathrm{C}$ while the mean relative humidity at noon varies between 14 and $74 \%$. The altitude ensures that the area is free from tsetse flies.

\subsection{Sampling and Sample Preparation}

A total of six samples each of two typical crops Tomato and Irish potato were chosen for the assessment. In accord with the reference methods, Plant samples (Tomato and Irish Potato) where collected both in mined out areas, at areas outside mine dumps and along stream channels where irrigation farming are taken place. The method employed was random sampling, 5-6 samples each of Tomato and Irish potato were taken as representative samples on each location (farms) with their corresponding GPS readings. Both potato tubers and tomato fruits were washed and oven dried at temperature of about $105^{\circ} \mathrm{C}$, measurements was controlled by inclusion of reference plant materials (NIST-RM 8412, IAEA-V-10) with a certified content of the analyzed trace elements.

\subsection{Analytical Procedure}

\subsubsection{Sample Preparation}

Twenty gram $(20.00 \mathrm{~g})$ of the sample is finely grounded to pass through a 200-250 mesh sieve. Depending on the nature of the sample, it is dried in an oven at $105^{\circ} \mathrm{C}$ for at least one hour and cooled. After which, the sample is intimately mixed with a binder in the ratio of $5.0 \mathrm{~g}$ sample(s) to $1.0 \mathrm{~g}$ cellulose flakes binder and palletized at a pressure of 10-15 tons/inch ${ }^{2}$ in a palletizing machine. At this stage, the palletized sample(s) are stored in a dessicator for analysis.

\subsubsection{Analysis}

The machine, ED-XRFS, is switched on and allowed to warm up for two hours. Finally, appropriate programs for the various elements of interest are employed to analyze the sample material(s) for their present or absence. The result of the analysis is either reported in part per million (ppm) or in percentage (\%), it can also be reported in $\mathrm{mg} / \mathrm{kg}$ for solid samples or in $\mathrm{mg} / \mathrm{ltr}$ for liquid samples. This is applying for both minor and major concentrations of elements.

\section{Results and Discussions}

The studied area was all parameters used to generate data and results were presented below.

Table 1. Mean concentrations of each element analyzed from tomato samples in $(\mathrm{mg} / \mathrm{kg})$.

\begin{tabular}{|c|c|c|c|c|c|c|c|c|c|}
\hline \multirow{2}{*}{$\frac{\text { S/No }}{1}$} & \multirow{2}{*}{$\frac{\text { Elements }}{\mathrm{Cu}}$} & \multicolumn{6}{|c|}{ Concentration in $\mathrm{mg} / \mathrm{kg}$ of tomato samples } & \multirow{2}{*}{$\frac{\text { Mean }}{76.2}$} & \multirow{2}{*}{$\begin{array}{l}\text { RangeMin Max } \\
53.5-110.2\end{array}$} \\
\hline & & 53.5 & 110.2 & 63.2 & 65.5 & 110.2 & 54.3 & & \\
\hline 2 & $\mathrm{Fe}$ & 218.2 & 196.5 & 392.3 & 189.5 & 197.3 & 218.2 & 235.3 & $196.5-392.3$ \\
\hline 3 & $\mathrm{Zn}$ & 6.4 & 5.6 & 104.4 & 612.9 & 6.4 & 104.4 & 140.0 & $5.6-612.9$ \\
\hline 4 & $\mathrm{Cr}$ & 21.2 & 7.5 & 34.9 & 15.7 & 21.2 & 21.2 & 20.3 & $7.5-34.9$ \\
\hline 5 & $\mathrm{Mn}$ & 12.4 & 13.2 & 209.1 & 17.8 & 138.4 & 139.4 & 67.5 & $12.4-209.1$ \\
\hline 6 & $\mathrm{Ni}$ & 3.9 & 7.9 & 7.9 & 7.9 & 7.9 & 7.9 & 7.2 & $3.9-7.9$ \\
\hline 7 & $\mathrm{~Pb}$ & ND & ND & ND & ND & ND & ND & ND & ND \\
\hline
\end{tabular}




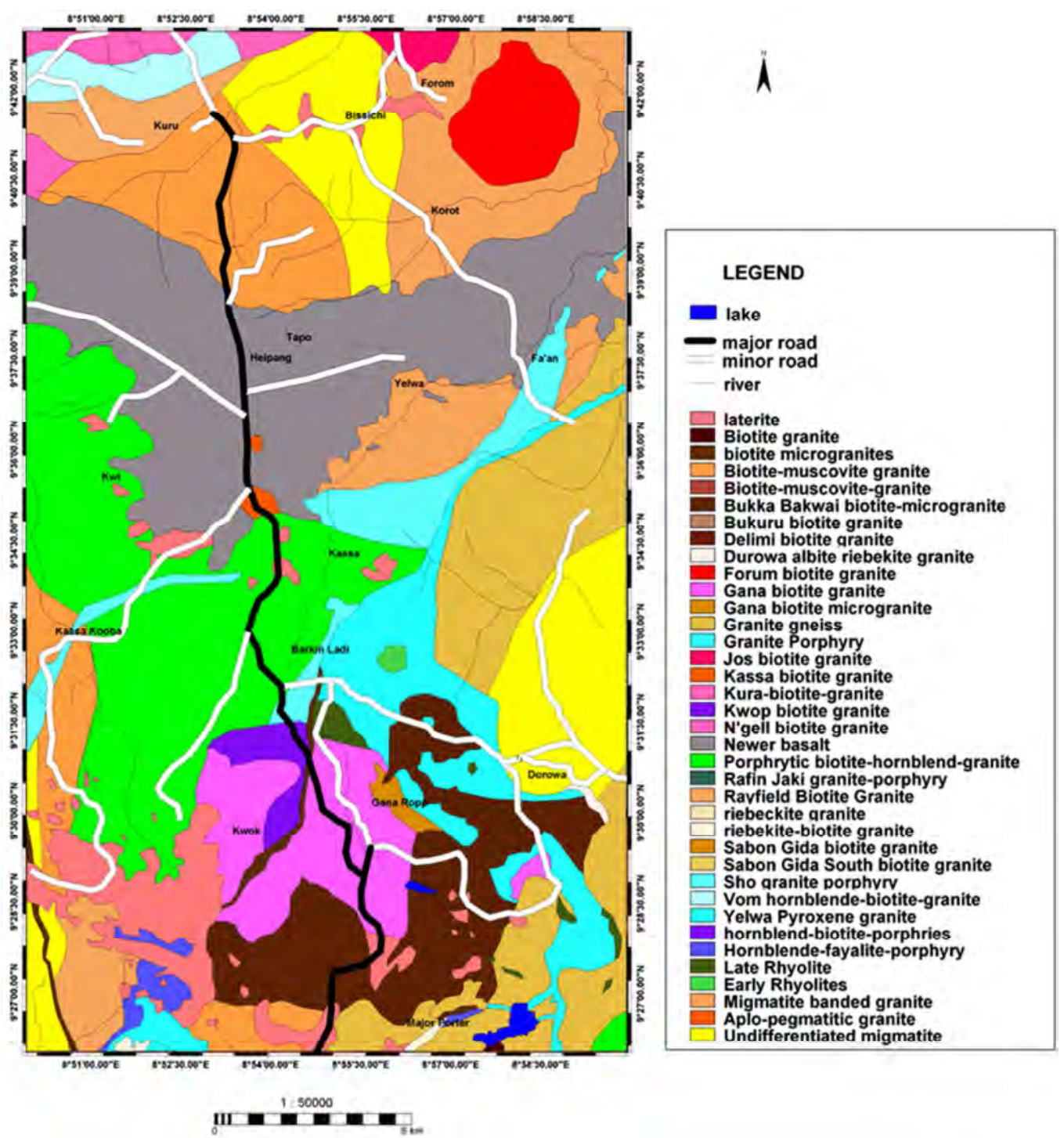

Source: National Centre for Remote Sensing Plateau State, Nigeria.

Figure 1. Geological map showing Locations of sampling sites for Tomato and Irish potato.

Table 2. Mean concentrations of each element analyzed from Irish potato sample in ( $\mathrm{mg} / \mathrm{kg})$.

\begin{tabular}{|c|c|c|c|c|c|c|c|c|c|}
\hline \multirow{2}{*}{$\begin{array}{l}\text { S/No } \\
1\end{array}$} & \multirow{2}{*}{$\begin{array}{l}\text { Elements } \\
\mathrm{Cu}\end{array}$} & \multicolumn{6}{|c|}{ Concentrations in $(\mathrm{mg} / \mathrm{kg})$ of irish potato samples } & \multirow{2}{*}{$\begin{array}{l}\text { mean } \\
82.2\end{array}$} & \multirow{2}{*}{$\begin{array}{l}\text { Range Min Max } \\
71.1-103.9\end{array}$} \\
\hline & & 96.1 & 103.9 & 80.7 & 86.3 & 73.5 & 71.1 & & \\
\hline 2 & $\mathrm{Fe}$ & 148.3 & 29.4 & 278.4 & 183.2 & 504.9 & 211.9 & 226.0 & $29.4-504.9$ \\
\hline 3 & $\mathrm{Zn}$ & 21.7 & 20.1 & 16.1 & 17.7 & 14.5 & 72.3 & 27.0 & $14.5-72.3$ \\
\hline 4 & $\mathrm{Cr}$ & 0.4 & 1.4 & 13.7 & 12.3 & 15.7 & 2.7 & 52.2 & $0.4-15.7$ \\
\hline 5 & $\mathrm{Mn}$ & 17.0 & 32.5 & 33.3 & 24.8 & 37.2 & 17.0 & 26.9 & $17.0-37.2$ \\
\hline 6 & $\mathrm{Ni}$ & 18.1 & 15.9 & 9.5 & 11.0 & 12.6 & 12.6 & 13.3 & $9.5-18.1$ \\
\hline 7 & $\mathrm{~Pb}$ & ND & ND & 1766 & 1377 & 1740 & ND & 1627 & ND-1766 \\
\hline
\end{tabular}

Table 3. Ranges of elements and their crustal abundance in plants.

\begin{tabular}{lllll}
\hline \multirow{2}{*}{ Names of elements } & \multicolumn{2}{l}{ Ranges of plant concentration in (mg/kg) } & Safe & \multicolumn{1}{c}{ Crustal abundance } \\
\cline { 2 - 4 } & Min. Range & Max. Range & 1000 \\
$\mathrm{Cu}$ & $7-30$ & $84-17000$ & 2500 & 8.7 \\
$\mathrm{Zn}$ & $21-70$ & $101-49000$ & - & 11 \\
$\mathrm{Mn}$ & $31-100$ & $32-9870$ & - & 170 \\
$\mathrm{Fe}$ & $21-70$ & - & 200 & 10,000 \\
$\mathrm{Cr}$ & 30 & $480-1300$ & 300 & 19 \\
$\mathrm{Ni}$ & 56 & $106-544000$ & - & 13 \\
$\mathrm{~Pb}$ & - & 1200 & - & - \\
\hline
\end{tabular}

Note: Where (ND) = Not Detectable. Sources: [11] [12]. 


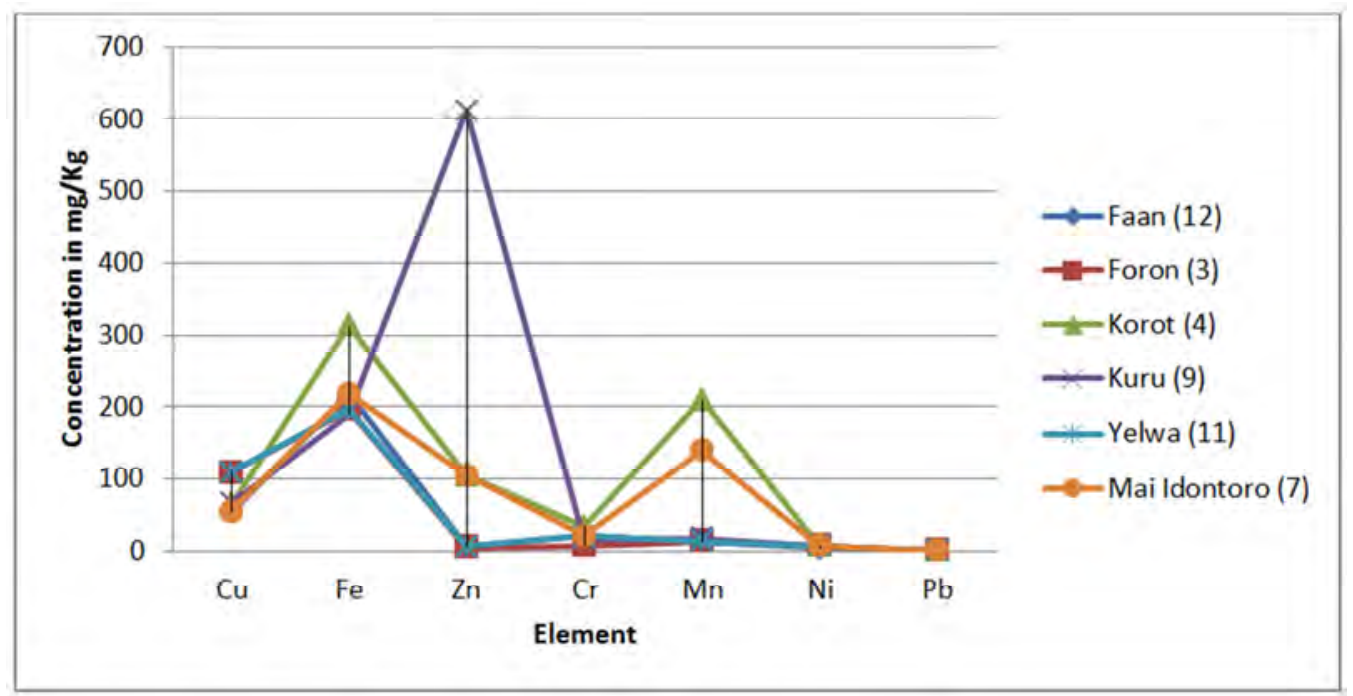

Figure 2. Graph showing the concentration of trace elements in tomato samples in $\mathrm{mg} / \mathrm{kg}$.

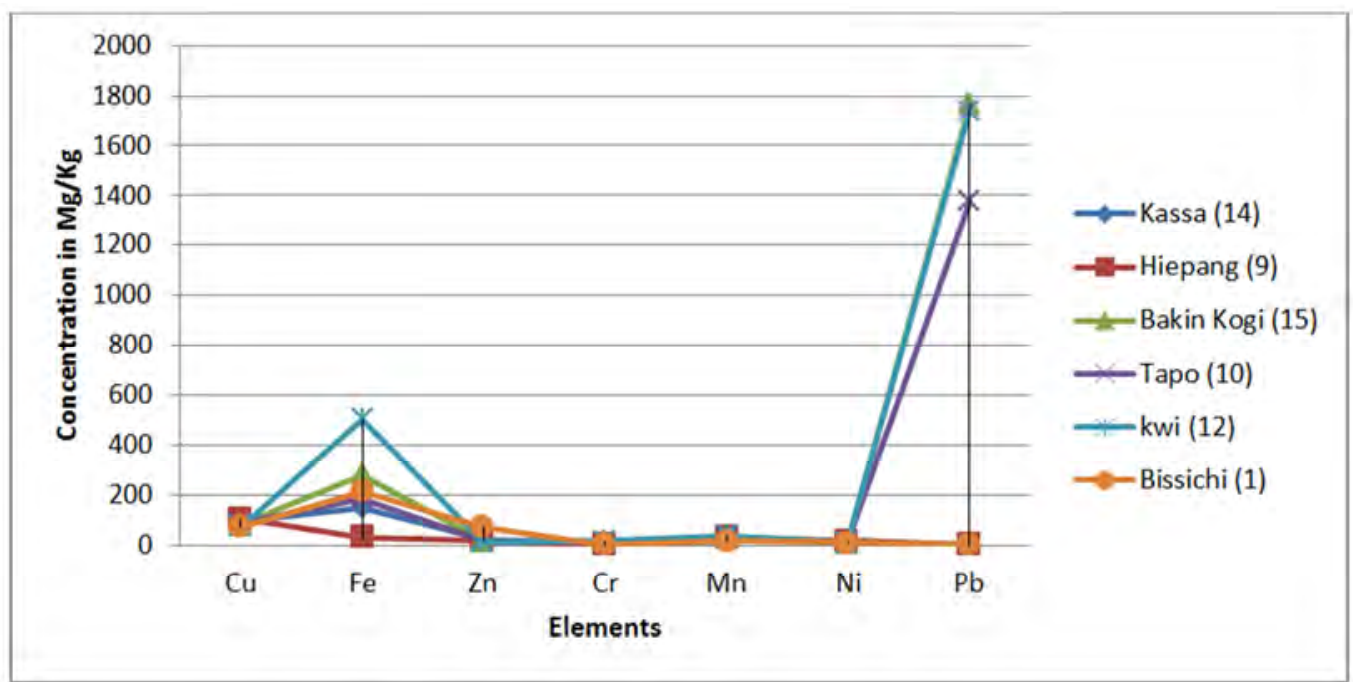

Figure 3. Graph showing the concentration of trace elements in Irish potato samples in $\mathrm{mg} / \mathrm{kg}$.

All the plants (Tomato and Irish potato) in the study area are summarized in (Tables 1 and 2) and in the graphs (2 and 3 ), display a very similar distribution pattern of trace elements. These similarities suggest that, the geologic processes associated with the release of these elements from the host rock and soil is the same. The distribution of trace element in tomato samples as shown in Table 3, when compared with the concentration of plants, shows that $\mathrm{Cu}$, $\mathrm{Zn}, \mathrm{Mn}, \mathrm{Fe}, \mathrm{Cr}$, Ni except $\mathrm{Pb}$ that was not detectable (ND) possesses values below the safe or permissible concentrations. Similarly, Table 2 shows that $\mathrm{Cu}, \mathrm{Zn}, \mathrm{Mn}, \mathrm{Fe}$, $\mathrm{Cr}$ and $\mathrm{Ni}$ except $\mathrm{Pb}$ exhibit the permissible concentration [7] [12].

Copper $(\mathrm{Cu})$; going by the safe concentration. $1000 \mathrm{mg} / \mathrm{kg}$ in (Table 3), the arithmetic mean values of copper from the analysis in both Tomato and Irish potato is $76.2 \mathrm{mg} / \mathrm{kg}$ and $82.2 \mathrm{mg} / \mathrm{kg}$ respectively from (Table 1 and 2), shows that the concentration of cupper within the study area is at a non objectionable rate in plant [2] [7].
The arithmetic mean values of Fe from the analysis of both Tomato and Irish potato as shown in Tables 1 and 2 having $235.3 \mathrm{mg} / \mathrm{kg}$ and $211.9 \mathrm{mg} / \mathrm{kg}$ values respectively. These, when correlated with its crustal abundance in Table 3, $10,000 \mathrm{mg} / \mathrm{kg}$. This showed that, the study area has high Fe concentration [2].

$\mathrm{Cr}$ and $\mathrm{Ni}$ concentrations are permissible both in Tomato and Irish Potato (Table 1 and 2). Their Arithmetic mean values in tomato and irish potato ranges from $20.3-52.2 \mathrm{Cr}$ and $7.2-13.2 \mathrm{Ni}$. These values are safe in both plants, except where it goes beyond the safe value in Table 3. This could cause cancer in man and would be so toxic to Plants when it exceeds the safe values.

The concentration of $\mathrm{Pb} 1,627 \mathrm{mg} / \mathrm{kg}$ in Irish potato exceeded the recommended value of $1,200 \mathrm{mg} / \mathrm{kg}$ (Table 3 ). This indicates that, the study area are cultivating and consuming objectionable concentration of $\mathrm{Pb}$ in the Irish potato. Even though there was no concentration of this metal was detected in tomato crop. However, the arithmetic mean 
values of $\mathrm{Mn}$, in tomato and Irish potato, $67.5 \mathrm{mg} / \mathrm{kg}$ and $26.9 \mathrm{mg} / \mathrm{kg}$ respectively as compared to the standard in Table 3 , shows that, the study area has the minimum concentration of this trace element [13].

In general the plant samples were found to have major, minor and mostly trace elements' concentrations below the safe value as shown in Table 3, however, $\mathrm{Pb}$ that has high concentration above the safe value (threshold limit) in the Irish potato is advised not to be cultivated, because of its adverse health effects on the inhabitants [14].

\section{Conclusions}

In general the plant samples were found to have major, minor and mostly trace elements' concentrations below the safe value. It is note worthy that irish potato accumulated $\mathrm{Pb}$ above the threshold limit which makes unsuitable for consumption.

The anomalous concentration of trace elements in the analyzed plant crops samples gives evidence of extensive mineralization and also the anomalous concentration of some trace elements like $\mathrm{Pb}, \mathrm{Fe}, \mathrm{Cr}, \mathrm{Ni}, \mathrm{Mn}$, etc. may also suggested that there is every tendency for the water to be affected by these elements due to remobilization into the water phase. The presence of gorges, abandoned mine, dams, mine pits, constitute a huge threat to the inhabitants of the area.

The research indicates also that, the prevalent high rate of cancer in the northern (Upper) part of Plateau State is as a result of high rate of cultivation and consumption of crops grown on mine dumps which makes people vulnerable to these toxic elements.

\section{References}

[1] Kabata-Pendias, H. (1999): Trace Elements in Soil and Plants, CRC Press, London, pg: 413.

[2] Turner, P. (1994). The response of plants to heavy metals. In: Toxic metals in soil-plant system. Ross, M. (ed.), John Wiley \& Sons Ltd., London, 153-182 pp.
[3] Karczewskaa, K. (2002). Metale ciê jkie w glebach zanieczyszczonych emisjami hut miedzi -formy i rozpuszczalnoœæ[Heavy metals in soils polluted by emissions from copper works - forms and solubility]. Zesz. Nauk. AR Wroc., 432: 159 ss. (in Polish).

[4] Wilson, B. and Pyatt, F. B. (2007). Heavy metal dispersion, persistence and bioaccumulation around an ancient copper mine situated Anglesey, UK. Ecotoxicol Environ Saf 66:224 231.

[5] WHO (1992). Cadmium Environmental Health Criteria. World Health Organization, Geneva, p 134.

[6] Steenland,K. and Boffetta, P. (2000). Lead and cancer in humans: where are we now? Am. J. Ind Med 38:295-299.

[7] ATSDR (2008): Minimal Risk Level. Agency for Toxic Substances and Disease Registry. www.atsdr.cdc.gov. accessed on $01 / 12 / 2008$.

[8] Maleki, Z., Zaresvand (2008). Heavy metals in selected edible vegetables and estimation of their daily intake in Sanandaj, Iran. Southeast Asian J. Trop Med Public Health 39(2):335340 .

[9] Lokeshappa, B, Shivpuri K, Tripath V, and Dikshit, A. K. (2012). Assessment of Toxic Metals in Agricultural Product. Food Pub Health 2(1):24-29.

[10] Sresty, T. V. S., Rao KVM. (1999). Ultra structural alternation in response to zinc and nickel stress in the root cells of pea. J Env Exp Bot 41:3-13.

[11] Lacatusu, R., Rauta, C., Carstea, S. and Ghelase, I. (1996). Soil - plant relationships in heavy metal polluted areas in Romania. Appl Geochem 11:105-107.

[12] Page, A. L. (1991): Methods of Soil Analysis. $2^{\text {nd }}$ edition. Am. Soc. Agron. \& Soil Sci. Am. Madison, Wisconsin, USA.

[13] Jarup, L. (2003). Hazards of Heavy Metal Contamination. Br. Med. Bull. 68:167-82.

[14] Alloway, B. J. (1994): Heavy Metals in Soils. London, Blackie Academic and Professional. Pp: 368-400. 